Journal of Engineering and Applied Sciences 14 (Special Issue 9): 10706-10710, 2019

ISSN: 1816-949X

(C) Medwell Journals, 2019

\title{
Application of WQI Model to Assessment of Water for Irrigation and Livestock Drinking Purpose: The Case Study, Ground Water Quality of Gleewkhan Village Southeastern of Mosul City Iraq
}

\author{
Waffaa E. Al Sinjari, Abdul-Aziz Y.T. Al-Saffawi and Yasir A.J. AL-Taee \\ Department of Biology, College of Education for Pure Science, \\ University of Mosul, Mosul, Iraq
}

\begin{abstract}
The present study is an attempt to assessment the groundwater quality of Gleewkhan village southeastern of Mosul city, for irrigation and livestock drinking by using WQI. Forty eight water samples were collected to determine their physical and chemical properties by using standard laboratory methods. From the analyzed data, some parameters like MAR, P.S and RSC have been calculated to identify the irrigational suitability, WQI model was applied for evaluation the groundwater for agricultural uses according to universal standard classification. It has been found that some of the measured parameters were high, especially, $\mathrm{Ec}_{25}$, P.S, MAR, Ca, Mg, $\mathrm{Cl}$ and $\mathrm{SO}_{4}$ ions which reached to $4652 \mu \mathrm{S} . \mathrm{cm}^{-1}$, (23.8,62, 22.4, 19.6, 17.6 and 23.8) meq. $\mathrm{l}^{-1}$ respectively, so, it was affected on water quality and would be considered as a very high salinity $\left(\mathrm{C}_{4}\right)$ according to USSL. Interestingly, the MAR, $\mathrm{Cl}, \mathrm{HCO}_{3}$ show that $\% 88$ of the water samples are suitable for irrigation practices with some problems appear due to high values of P. salinity. Also, the results analysis of (WQI) confirm that, the groundwater in the study area ranged between class I (Excellent) to class II (Very good) categories for livestock drinking and class II (Very good) to class III (Marginal) categories for irrigation purpose. So, these groundwater should be used only with the soil having high permeability with some constraints imposed on types of plant for specified tolerance of salts.
\end{abstract}

$\underline{\text { Key words: WQI, groundwater quality, irrigation and livestock suitability, Gleewkhan village, parameters }}$

\section{INTRODUCTION}

Irrigation water quality directly affects soils and crops, it is possible to produce high quality crops only by using high irrigation water quality when other inputs are kept optimal. Characteristics of irrigation water can vary with the source of the water. Regional differences in water characteristics will result from variation of geology and climate and climatic parameter's are the most important factors related to irrigation (Rahman et al., 2012). Moreover, there may also be great differences in the quality of water available on a local level depending on whether the source is from surface water bodies (e.g., rivers and ponds) or from aquifers with varying geology and whether the water has been chemically treated. The chemical constituents of irrigation water can affect plant growth directly through toxicity or deficiency or indirectly by altering plant availability of nutrients (Singh et al., 2016).

Water resources in Iraq, especially in the last two decades have also suffered of remarkable stress in terms of water quantity due to different reasons such as the dams built on Tigris and Euphrates in the riparian countries, the global climatic changes and the local severe decrease of the annual precipitation rates and improper planning of $\mathrm{w}$ ater uses inside Iraq.

Therefore, the index techniques have been developed as a result of this need, the concept of indices to represent gradations in water quality was first proposed by Simsek and Gunduz (2007). So far, many researches and projects have been conducted to measure water quality index. AlHussain (1998) used Water Quality Index (WQI) as a management tool for water quality within Mosul city for irrigation and different uses. Al-Saffawi (2008) assessed the status and the suitability of the Tigris river water in Mosul city for agriculture use. Al-Saffawi (2013) classify ground water quality Southeastern Mosul city by using WQI for irrigation use. Al-Saffawi (2013) studied the evaluation of groundwater in Northwestern of Mosul city for irrigation and livestock drinking uses by using WQI model. Al-Saffawi and Mahmoud (2018) used Water Quality Index (WQI) to assess the water quality of Al-Kasik sub district northwestern of Mosul city. Iraq for irrigation purpose.

Corresponding Author: Abdul-Aziz Y.T. Al-Saffawi, Department of Biology, College of Education for Pure Science, University of Mosul, Mosul, Iraq 
The main objective of this paper is to assess the suitability of groundwater quality at Gleewkhan village Southeastern of Mosul city for irrigation and livestock drinking by application of WQI model.

\section{MATERIALS AND METHODS}

Study site: The study was conducted on groundwater of Gleewkhan village southeastern of Mosul city, Iraq. It is located between $36^{\circ} 17^{\prime} 7.9^{\prime \prime}$ and $36^{\circ} 17^{\prime} 18.7^{\prime \prime}$ North Latitude and $43^{\circ} 14^{\prime} 27.6^{\prime \prime}$ and $43^{\circ} 14^{\prime} 40.2^{\prime \prime}$ East Longitude (Fig. 1), the groundwater in the study areausing for irrigation and livestock drinking.

The geological formation in it is Al-Fatha (Lower Fars) which consisting mainly of gypsum, anhydrite, evaporated salts, limestone and marl, etc. (Al-Sawaf, 1977). Therefore, the water well be contains high levels of sulfur compounds as sulfate, sulphite which combined with other cations (Al-Saffawi, 2018).

In present study forty eightwater sample taken from eight different wells (through dry seasons, for 3 months) were collected through a period from May to Join 2014 (twice replicates a month) in polythene bottles which were cleaned with distilled water; followed by rinsing the sample container with the sample before it is filled. The parameters like $\mathrm{pH}, \mathrm{EC}_{25}$, Calcium, Magnesium, Chloride, Sulfate, $\mathrm{HCO}_{3}$ and Nitrate were estimated by using standard methods (APHA, 1998). The irrigation parameters like residual sodium carbonate, magnesium adsorption and potential salinity were estimated in order to access the irrigation quality of sampled water studied, these parameters were calculated by the following equation (Aladejana and Talabi, 2013) as:
MAR : $\left(\mathrm{Mg}^{*} 100\right) /(\mathrm{Ca}+\mathrm{Mg})$

$\mathrm{RSC}:\left(\mathrm{CO}_{3}+\mathrm{HCO}_{3}\right)-(\mathrm{Ca}+\mathrm{Mg})$

P.S : $1 / 2 \mathrm{SO}_{4}+\mathrm{Cl}$ where, all the ions are expressed in meq. $\mathrm{l}^{-1}$

Water Quality Index (WQI) computation: In this study, Water Quality Index (WQI) was done by multiplicative weighted mean) Geometric mean) index according to Bhargava method. This method was adopted because of its simplicity involved in handling small to large data for various beneficial uses. The simplified model for WQI for a beneficial use is given by equation (Poonam et al., 2013):

$$
\text { WQI }=[\pi \mathrm{fi}(\mathrm{pi})]^{1 / \mathrm{n}} \mathrm{x} 100
$$

where, WQI is the water quality index it value ranged between $0.0-100$, ( $\mathrm{f} \mathrm{i}$ ) P i is thesensitivity function of the $i$ th variable which includes the effect of weighting of thei th variable in the use and $n$ is the number of variables is considered more relevant to the use.

The sensitivity function values of different concentrations of the various quality variables with respect to standard criteria, to compute WQI values for assessing groundwater quality for irrigation and livestock drinking, four parameters were chosen like $\mathrm{pH}, \mathrm{EC}_{25}, \mathrm{SO}_{4}$ and $\mathrm{Cl}$, the computed WQI values are classified into five class (Table 1).

\begin{tabular}{lll}
\multicolumn{2}{l}{ Table 1: WQI based classification of water quality } & (Bahargava, 1983) \\
\hline WQI values & Class & Category \\
\hline $100-90$ & I & Excellent \\
$89-65$ & II & Very good \\
$64-35$ & III & Marginal \\
$34-11$ & IV & Poor \\
$\leq 10$ & V & Very poor \\
\hline
\end{tabular}

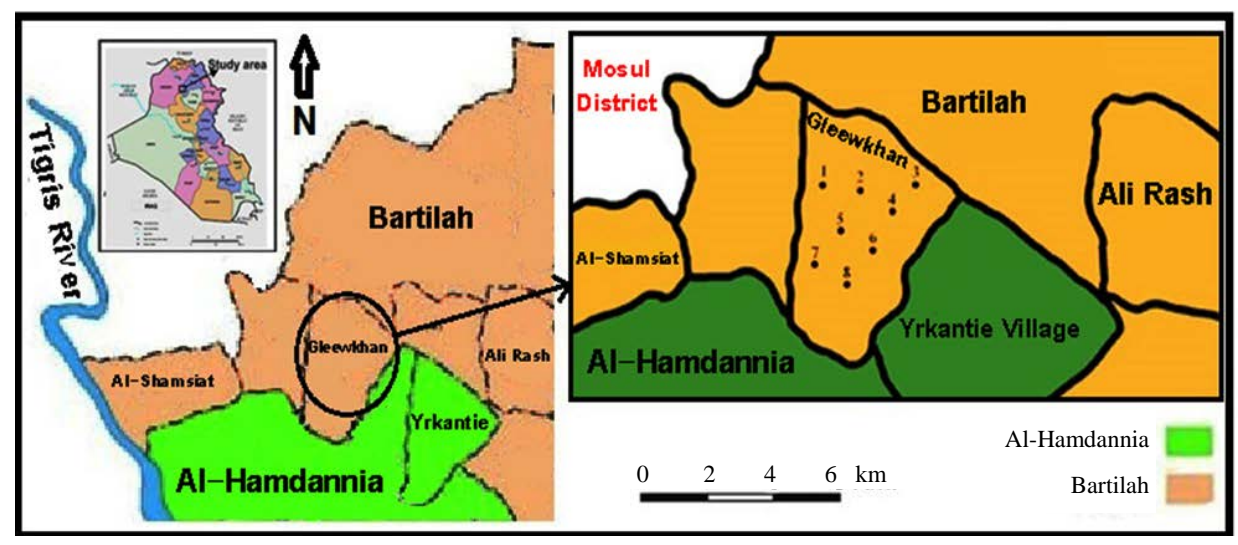

Fig. 1: Map of Nineveh Governorate showing study area 


\section{RESULTS AND DISCUSSION}

The values of physicochemical parameters of forty eight samples are given in Table 2. The $\mathrm{pH}$ of water is an important indication of its quality and provides significant information in many types of geochemical equilibrium solubility calculation (Mumtazuddin et al., 2012). The $\mathrm{pH}$ of the groundwater in the study area varied from 6.86-7.86. The slight acidic of some samples may be due to the presence of dissolved carbon dioxide and organic acids in the groundwater which are derived from the decay and subsequent leaching of plant materials (Bakari, 2014), However, the $\mathrm{pH}$ values of the samples under study are well within the normal range of $\mathrm{pH}$ (6.5-8.5) for irrigation (Al-Saffawi, 2018). EC is the most important parameter to demarcate salinity hazard and suitability of water for livestock drinking and irrigation purposes and changes in its concentration signify water quality deterioration (Vema and Kumar, 2014). The values ranged from $1800-4200 \mu \mathrm{S} . \mathrm{cm}^{-1}$. The values of water samples of Gleewkhan village indicate that, 34\% of samples are in the range of low salinity hazard and 64\% in the range of medium salinity hazard (Simsek and Gunduz, 2007). According to USSL for salinity classification, all the irrigation water samples fell under class $\left(\mathrm{C}_{4}\right)$ high salinity hazard (Richards, 1954). The primary effect of high $\mathrm{Ec}_{25}$ in irrigation water is the inability of plant to compete with ions in the soil (Naseem et al., 2010).

Table 2: Results of water quality analysis for the groundwater in the study area (meq. $\mathrm{l}^{-1}$ )

\begin{tabular}{|c|c|c|c|c|c|c|c|c|c|c|c|}
\hline Well No. & $\mathrm{pH}$ & $\mathrm{EC}_{25} *$ & $\mathrm{Ca}$ & $\mathrm{Mg}$ & $\mathrm{Cl}$ & $\mathrm{SO}_{4}$ & $\mathrm{HCO}_{3}$ & $\mathrm{NO}_{3}$ & RSC & P.S & MAR \\
\hline \multicolumn{12}{|l|}{1} \\
\hline Min. & 7.06 & 2592 & 6.80 & 6.20 & 3.50 & 10.9 & 8.00 & 0.172 & -9.80 & 10.8 & 44.9 \\
\hline Max & 7.59 & 4071 & 12.6 & 12.8 & 7.30 & 14.6 & 9.40 & 0.175 & -14.2 & 13.0 & 62.0 \\
\hline Mean & 7.31 & 2998 & 8.72 & 10.6 & 5.10 & 12.3 & 8.53 & 0.174 & -11.9 & 11.2 & 54.6 \\
\hline $\begin{array}{l}\mathrm{Sd} \pm \\
2\end{array}$ & 0.18 & 570 & 2.13 & 2.59 & 1.30 & 1.40 & 0.47 & 0.001 & -1.80 & 1.03 & 6.17 \\
\hline Min. & 7.23 & 2200 & 7.60 & 6.20 & 3.00 & 3.10 & 5.40 & 0.171 & -9.69 & 5.90 & 40.8 \\
\hline Max & 7.73 & 3140 & 11.2 & 13.2 & 5.40 & 7.20 & 8.40 & 0.173 & -13.0 & 9.60 & 60.1 \\
\hline Mean & 7.42 & 2634 & 9.00 & 8.40 & 4.50 & 5.10 & 6.60 & 0.172 & -11.5 & 7.85 & 47.5 \\
\hline \multicolumn{12}{|l|}{3} \\
\hline Min. & 7.37 & 2530 & 8.60 & 5.40 & 4.00 & 4.80 & 2.40 & 0.111 & -8.60 & 9.60 & 33.8 \\
\hline Max & 7.57 & 2688 & 12.2 & 6.80 & 10.2 & 11.2 & 5.40 & 0.173 & -16.0 & 13.2 & 42.5 \\
\hline Mean & 7.51 & 2599 & 10.2 & 6.12 & 6.80 & 8.50 & 3.36 & 0.130 & -13.0 & 11.4 & 37.9 \\
\hline $\mathrm{Sd} \pm$ & 0.10 & 51.5 & 1.39 & 0.59 & 2.50 & 3.10 & 1.05 & 0.020 & -2.73 & 1.45 & 3.34 \\
\hline \multicolumn{12}{|l|}{4} \\
\hline Min. & 6.96 & 1800 & 10.2 & 4.40 & 3.90 & 5.00 & 6.20 & 0.174 & -8.70 & 7.85 & 32.5 \\
\hline Max & 7.49 & 2931 & 14.0 & 12.4 & 6.60 & 9.00 & 9.60 & 0.177 & -18.2 & 9.10 & 50.9 \\
\hline \multicolumn{12}{|l|}{ M } \\
\hline ean & 7.11 & 2356 & 11.4 & 8.40 & 5.10 & 6.80 & 7.68 & 0.175 & -14.0 & 8.49 & 43.5 \\
\hline \multicolumn{12}{|l|}{5} \\
\hline Min. & 7.22 & 2100 & 4.60 & 6.00 & 3.10 & 8.70 & 5.00 & 0.169 & -7.00 & 5.60 & 41.3 \\
\hline Max & 7.67 & 3573 & 9.76 & 11.8 & 5.00 & 9.60 & 9.40 & 0.174 & -11.8 & 9.70 & 52.0 \\
\hline Mean & 7.43 & 2634 & 7.74 & 7.92 & 3.70 & 9.10 & 6.88 & 0.172 & -9.89 & 7.10 & 45.5 \\
\hline $\mathrm{Sd} \pm$ & 0.16 & 570 & 2.06 & 2.04 & 0.79 & 0.33 & 1.47 & 0.001 & -1.79 & 1.55 & 4.68 \\
\hline \multicolumn{12}{|l|}{6} \\
\hline Min. & 7.04 & 2640 & 12.2 & 5.20 & 3.00 & 6.70 & 6.80 & 0.173 & -9.80 & 8.65 & 21.7 \\
\hline Max & 7.54 & 4652 & 22.4 & 10.6 & 10.0 & 19.3 & 9.80 & 0.175 & -12.5 & 15.5 & 36.2 \\
\hline Mean & 7.25 & 3474 & 16.9 & 7.12 & 6.80 & 11.3 & 7.86 & 0.174 & -16.5 & 12.9 & 27.7 \\
\hline $\mathrm{Sd} \pm$ & 0.19 & 696 & 4.49 & 1.84 & 3.10 & 3.90 & 1.16 & 0.001 & -5.41 & 2.30 & 5.63 \\
\hline \multicolumn{12}{|l|}{7} \\
\hline Min. & 6.86 & 2430 & 14.8 & 13.0 & 3.10 & 6.60 & 5.00 & 0.112 & -12.4 & 9.15 & 46.1 \\
\hline Max & 7.56 & 4652 & 21.8 & 19.6 & 7.10 & 12.1 & 6.60 & 0.173 & -35.2 & 10.7 & 51.3 \\
\hline Mean & 7.05 & 3414 & 18.2 & 15.4 & 5.20 & 8.80 & 5.90 & 0.127 & -23.9 & 10.2 & 48.2 \\
\hline $\begin{array}{l}\mathrm{Sd} \pm \\
8\end{array}$ & 0.26 & 734 & 3.18 & 2.62 & 1.60 & 2.00 & 0.62 & 0.021 & -9.31 & 0.64 & 2.22 \\
\hline Min. & 7.26 & 2670 & 11.8 & 8.00 & 7.10 & 10.2 & 5.40 & 0.132 & -16.2 & 19.1 & 32.8 \\
\hline Max & 7.86 & 4200 & 20.0 & 15.6 & 17.4 & 23.8 & 8.00 & 0.174 & -23.8 & 23.8 & 46.8 \\
\hline Mean & 7.44 & 3474 & 15.9 & 11.6 & 13.0 & 16.8 & 6.40 & 0.166 & -19.3 & 21.2 & 41.6 \\
\hline $\mathrm{Sd} \pm$ & 0.21 & 605 & 2.96 & 2.78 & 4.05 & 5.70 & 0.92 & 0.015 & -2.81 & 1.57 & 5.28 \\
\hline
\end{tabular}


J. Eng. Applied Sci., 14 (Special Issue 9): 10706-10710, 2019

Table 3: Evaluation result of groundwater for irrigation and livestock drinking purposes

\begin{tabular}{|c|c|c|c|c|c|c|c|c|c|c|c|}
\hline \multirow[b]{2}{*}{ Well No. } & \multicolumn{3}{|c|}{ WQI for livestock } & \multicolumn{3}{|l|}{ IWQI } & \multicolumn{5}{|c|}{ Irrigation indexes } \\
\hline & Value & Class & Quality & Value & Class & Quality & EC & MAR & P. S & $\mathrm{Cl}$ & RSC \\
\hline$\overline{1}$ & 95 & I & Ex. & 62 & II & V.G & $\mathrm{C}_{4}$ & unsuit & M-P & M.S & Safe \\
\hline 2 & 97 & I & Ex. & 78 & II & V.G & $\mathrm{C}_{4}$ & suitab & M-P & M.S & Safe \\
\hline 3 & 95 & I & Ex. & 69 & II & V.G & $\mathrm{C}_{4}$ & suitab & M-P & M.S & Safe \\
\hline 4 & 98 & I & Ex. & 79 & II & V.G & $\mathrm{C}_{4}^{4}$ & suitab & M-P & M.S & Safe \\
\hline 5 & 97 & I & Ex. & 74 & II & V.G & $\mathrm{C}_{4}$ & suitab & M-P & H.S & Safe \\
\hline 6 & 93 & I & Ex. & 56 & III & M. & $\mathrm{C}_{4}$ & suitab & M-P & M.S & Safe \\
\hline 7 & 99 & I & Ex. & 64 & III & M. & $\mathrm{C}_{4}$ & suitab & M-P & M.S & Safe \\
\hline 8 & 72 & II & V.G & 44 & III & M. & $\mathrm{C}_{4}$ & suitab & Poor & L.S & Safe \\
\hline
\end{tabular}

Ex.: Excellent, V.G: Very Good, L: Low, M: Medium, H: High, P: Poor, S: Suitability, M: Marginal

Magnesium Adsorption Ratio (MAR) causes a harmful effect to soil when exceed a value of $50 \%$ (Ayers and Westcot, 1985). Although, most groundwater $\mathrm{Ca}^{2+}$ and $\mathrm{Mg}^{2+}$ maintain a state of equilibrium. During equilibrium more $\mathrm{Mg}^{2+}$ in groundwater adversely affects the soil quality rendering it alkaline which result in decrease of crop yield (Obiefuna and Sheriff, 2011). In present study, average MAR, Ca and Mg ranged from 21.7-62.0\%, 7.74-18.2 and 6.12-15.4 meq. $\mathrm{l}^{-1}$, respectively, therefore, considered most of water samples suitable for irrigation purpose (Table 3).

The concentration of bicarbonate and carbonate influences the suitability of water for irrigation purpose. The water with high RSC has high $\mathrm{pH}$. Therefore, land irrigated with such water becomes infertile owing to deposition of sodium carbonate (Obiefuna and Sheriff, 2011).

The RSC values of water samples vary from -35.2 to -7.0 meq. ${ }^{-1}$. Further, the value of RSC is negative values at all sampling wells, indicating that there is no complete precipitation of calcium and magnesium (Dhembare, 2012; Al-Saffawi, 2018), therefore, RSC is satisfied in the study area. According to $\mathrm{HCO}_{3}$ ions, there are $82 \%$ of samples fall under category 'medium suitability (Table 3). Although, ordinary $\mathrm{HCO}_{3-}$ is not toxic but it can cause zinc deficiency in rice and this is severe when zinc exceeds $2 \mathrm{meq}^{-1}$ in irrigation water (Asamoah et al., 2015).

Chloride are defining as a common toxic ion which cause damage to plant when concentration in a high amount in irrigation water or soil. The chloride concentrations were within the range of 3.0-17.4 meq. $\mathrm{l}^{-1}$. The results indicate that, the samples fall inmoderate to high suitability for irrigation (Ayers and Westcot, 1985).

Sulfate ion is a main contributor to the total salt content in irrigationwaters and has fertility benefits for crops but high sulfate ions inirrigation water canreduces phosphorus availability to plants. The sulfate $\left(\mathrm{SO}_{42}-\right)$ values in the watersample varied from 3.1-23.8 meq. ${ }^{-1}$ Chloride and sulfate hazards in water were also measured with respect to concentration of Potential Salinity (PS). The average values of the groundwater varied between 7.1-21.2 meq. $\mathrm{l}^{-1}$. According to P. Salinity, the groundwater samples fall under category medium suitability to poor for irrigation (Table 3).

Nitrate is the fundamental exporter of nitrogen to most plants as it is generally employed as a compost. In spite of that, using immoderate amounts of nitrate could reduce the yield or the crop quality because it delays the crop ripeness, Livestock health can also be affected by nitrate contamination. High-nitrate water is considered a health hazard. In animals, symptoms of methemoglobinemia include a lack of coordination, labored breathing, blue membranes, vomiting and abortions (Wedin and Sorensen, 2014). In present study, the average values of $\mathrm{NO}_{3-}$ ranged from 0.127-0.175 meq. $\mathrm{l}^{-1}$, respectively, higher values it may be due the excess use of fertilizers and pesticides (Patel et al., 2017), therefore, considered that, all groundwater belong to high suitability for irrigation (Simsek and Gunduz, 2007) and safe for livestock drinking purpose (Wedin and Sorensen. 2014) look at Table 3.

Assessment groundwater for irrigation and livestock drinking: Evaluation of groundwater quality for irrigation were carried out using different parameters like MAR, RSC, P. salinity, $\mathrm{pH}, \mathrm{Cl}, \mathrm{HCO}_{3}, \mathrm{NO}_{3}$ and EC (Table 3); most results of MAR, RSC. $\mathrm{Cl}, \mathrm{NO}_{3}$ and $\mathrm{pH}$ implying that the groundwater samples fall under suitable category. But based on EC and P.S, the samples fall under medium poor to poor suitability and very high salinity $\left(\mathrm{C}_{4}\right)$ respectively. Also, most groundwater samples fall medium suitable category according to Chloride ions. The estimated Irrigation Water Quality Index (IWQI) revealed that $75 \%$ of groundwater in the study area fell in very good water and $25 \%$ were in medium categories for irrigation uses, respectively.

To evaluate groundwater quality for livestock drinking according to $\mathrm{NO}_{3}$, all groundwater samples are safe and the computed results of WQI revealed that, the groundwater samples varied between excellent quality (class I) to very good (class II) categories for livestock drinking. 


\section{CONCLUSION}

The classification of irrigation water according to RSC, MAR, $\mathrm{NO}_{3}, \mathrm{Cl}$ and $\mathrm{pH}$ values, all the groundwater samples are suitable for irrigation purposes.

Irrigation water quality based on P. S and $\mathrm{EC}_{25}$ indicates that the water samples ranged between "medium poor" to poor and very high salinity $\left(\mathrm{C}_{4}\right)$ respectively. The estimated Irrigation Water Quality Index (IWQI) revealed that, 75\% of groundwater in the study area fell in very good water for irrigation uses.

For livestock drinking, the groundwater quality are safeaccording to $\mathrm{NO}_{3}$ and computed results of (WQI) varied between excellent quality (class I) to very good (class II) categories.

\section{RECOMMENDATIONS}

Therefore, we recommended for effective groundwater and irrigationmanagement, as well as, chosen salinity tolerant plant species for agriculture in the study area.

\section{REFERENCES}

APHA, 1998. Standard Method for the Examination of Water and Wastewater. 20th Edn., America Water Works Association and Water Pollution Control Federation, Washington, DC., USA.

Al-Hussain, M.H., 1998. Establishment WQI for Tigris River within Mosul City. MSc Thesis, Engineering Collage, University of Mosul, Mosul, Iraq.

Al-Saffawi, A.A.Y., 2008. Suitability of Tigris river water and discharged wastewater in Mosul city for irrigation uses. Tikrit J. Pure Sci., 13: 192-199.

Al-Saffawi, A.A.Y.T., W.E. Al-Sanjary and Y.A.J. Al-Taee, 2018. Assessment of groundwater quality using (WQI) in Gleewkhan village Northeastern of Iraq. Intl. J. Enhanced Res. Sci. Tech. Eng., 7: $1-7$.

Al-Saffawi, A.Y.T., 2013. Qualitative evaluation of groundwater in Northwestern Mosul city region. J. Al Rafidain Environ., 5: 33-44.
Al-Saffawi, A.Y.T., 2018. Assessment of groundwater for irrigation and domestic suitability by using (WQI) in Singiar district eastern of Mosul city Iraq. Mesopo. Environ. J. Special Issue F., 1: 75-84.

Aladejana, A.J. and A.O. Talabi, 2013. Assessment of Groundwater Quality in Abeokuta Southwestern, Nigeria. Int. J. Eng. Sci., 2: 21-31.

Asamoah, E., K.A. Nketia, A. Sadick, D.A. Gyambibi and E.K. Forkuo et al., 2015. Water quality assessment of lake Bosomtwi for irrigation purpose, Ghana. Intl. J. Agric. Crop Sci., 8: 366-372.

Ayer, R.S. and D.W. Westcot, 1985. Water quality for agriculture, irrigation and drainage. Food and Agriculture Organization of the United Nations, Rome, Italy. http://www.fao.org/ 3/T0234E/T0234E00.htm

Naseem, S., S. Hamza and E. Bashir, 2010. Groundwater geochemistry of Winder agricultural farms, Balochistan, Pakistan and assessment for irrigation water quality. Eur. Water, 31: 21-32.

Obiefuna, G.I. and A. Sheriff, 2011. Assessment of shallow ground water quality of Pindiga Gombe Area, Yola Area, NE, Nigeria for irrigation and domestic purposes. Res. J. Environ. Earth Sci., 3: 131-141.

Patel, T.M., P.K. Mahour, R.K. Mahour, H.K. Lautre and P.J. Shah, 2017. Physico-chemical analysis of ground water quality of Bhanvad. Intl. J. Econ. Energy Environ., 2: 87-89.

Poonam, T., B. Tanushree and C. Sukalyan, 2013. Water quality indices important tools for water quality assessment: A review. Intl. J. Adv. Chem., 1: $15-28$.

Rahman, M., S.H. Rahma and R.K. Majumder, 2012. Groundwater quality for irrigation of deep aquifer in southwestern zone of Bangladesh. Songklanakarin J. Sci. Technol., 34 : 345-352.

Simsek, C. and O. Gunduz, 2007. IWQ index: A GIS-integrated technique to assess irrigation water quality. Environ. Monit. Assess., 128: 277-300.

Singh, S., M. Singh, M.A. Bhat and A. Bhawsar, 2016. Evaluation of water quality index of Upper Lake-ARamsar site. Arch. Appl. Sci. Res., 8: 34-37.

Wedin, L. and F. Sorensen, 2014. Nitrate in drinking water. University of Alaska Fairbanks, USA. 